\title{
利用者の意識に基つくく冬期道路交通サービスの評価に関する研究
}

\section{A Study on Evaluation of the Winter Road Traffic Service based on User Concerns}

\author{
李 泰 榮*1 .三 村 泰 広*2 \\ Taiyoung Lee Yasuhiro Mimura \\ 川本 義 海 ${ }^{3} \cdot$ 本 多 義 明*4 \\ Yoshimi Kawamoto Yoshiaki Honda
}

\begin{abstract}
This study aims to clarify process of outcome index on winter road traffic service based on user concerns. Firstly, we carry out questionnaire survey on user concerns in order to grasp their actual condition of trip and daily activity cause influence to satisfaction of administrative road improvement in snowfall. Secondly, we clarify causal relationship between actual condition of user's trip and activity and evaluation to administrative road improvement by Covariance Structure Analysis method. Finally, we clarify process of outcome index methodically reflecting user concerns to winter road traffic service by causal structure model.
\end{abstract}

Keywords : winter road traffic service, outcome index, user concerns, causal relationship

1.はじめに

\section{1-1. 研究の背景}

降積雪時の道路状況の悪化は, 地域住民のモビリ ティを著しく低下させ，地域住民の日常生活に直接 影響を与えている。また，行政への依存体質，人々 の活動範囲の広域化などによって道路除雪の需要は 増大しているものの，財政上の制約，また核家族化 や高齢化などによる社会的な道路の耐雪・克雪能力 は急速に低下していることが懸念されている。特に, 高齢化・過疎化が深刻に進んでいる農山村地域では, そもそも幹線道路の密度が低いことに加え，これが 日常の生活道路として使用されていることや，また 公共交通機関のサービス水準が低く自動車に大きく 依存しているのが一般的である。そのため，降積雪 による走行環境や歩行環境の悪化を背景とした冬期 のハンディキャップを克服したいという地域住民の 要望や除排雪に対する需要が一層高まっていること から，地域住民のニーズに基づく効率的かつ効果的
な道路の管理運用のための評価が重要となっている。 現在，国土交通省をはじめとした各地方自治体レ ベルでは，地域が抱えている道路の管理運用面の問 題点に対する改善策を指標 ${ }^{2}$ ) として表し，道路交 通サービスに関する地域ごとの実態に相応しい成果 指標 ${ }^{2} 2$ を提案しつつある。しかしながら，このよ うな指標の提案における考え方や過程が必ずしも明 確化されていないため，実質的には道路交通サービ スに対する地域実態や道路利用者の意識が体系的に 反映された指標であるとは言い難い状況にある。そ のため, 利用者の視点を明示的に反映した道路交通 サービスの提供のためには, 道路の管理運用に関連 した施策や事業を評価する上で必要となる成果指標 の提案までのプロセスの体系的な検討が必要となる。

\section{1-2. 本研究における成果指標の考え方}

近年，国土交通省では行政マネジメントの成果主 義運営への転換により, 道路の管理運用に関わる各

* 1 福井大学大学院工学研究科システム設計工学専攻 修士（工学）

*2 (財) 豊田都市交通研究所 研究員 博士 (工学)

* 3 福井大学大学院工学研究科 助教授 博士 (工学)

* 4 福井大学副学長 工学博士

[本稿受理：2005年11月28日，修正原稿受理：2006年 3 月 7 日，討論期限：2007年 3 月31日] 


\section{表-1 国土交通省の成果指標の例}

\begin{tabular}{|c|c|}
\hline $\begin{array}{c}\text { 経済 } \\
\text { 効果に } \\
\text { 関するもの }\end{array}$ & $\begin{array}{l}\text { (1)渋滞損失時間・損失金額 } \\
\text { (2)都市計画道路が整備された市街地の居住寸る人口率 } \\
\text { (3) E T C 利用率 } \\
\text { (4)自動車専用道路交通分担率 }\end{array}$ \\
\hline $\begin{array}{l}\text { 利便性 } \\
\text { 向上に } \\
\text { 関するもの }\end{array}$ & $\begin{array}{l}\text { (5)利用者満足度 } \\
\text { (6)地域間交流ルート確保率 } \\
\text { (7)日常活動圈中心 心の安定到達率 } \\
\text { (8)情報公開度 }\end{array}$ \\
\hline $\begin{array}{l}\text { 環境 } \\
\text { 向上に } \\
\text { 関するもの }\end{array}$ & $\begin{array}{l}\text { (9) } \mathrm{NO}_{2} 、 \mathrm{SPM} \text { 環境目標達成箇所数 } \\
\text { (10)自動車 } \mathrm{CO}_{2} \text { 排出消減量 } \\
\text { (11)夜間騒音要請限度達成率 } \\
\text { (12)無電柱化率 } \\
\text { (13)構造物保全率 }\end{array}$ \\
\hline $\begin{array}{l}\text { 安全性 } \\
\text { 向上に } \\
\text { 関するもの }\end{array}$ & $\begin{array}{l}\text { (14)バリアフリー化率 } \\
\text { (15)害時救援ルート確保率 } \\
\text { (16)路上工事密度 } \\
\text { (18)死能維持事故率・死者率 }\end{array}$ \\
\hline
\end{tabular}

出展 : 主要指標現況值算出マニュアル (案) (平成 14 年)

種事業の達成度や効果を反映した成果指標を表一 1 のように定め, これに基づき行政運営を行う方式に 組織や行政プロセスを転換している。そのため, 事 業評価の説明責任や事業の透明性を確保するように なってきており，利用者の立場に立ち成果を定量的 に表す成果指標を政策目標ごとに定めるとともに, それを実現するためのプロセスを明確化することが 必要となっている11。

このプロセスの明確化のために, 本研究では以下 の二つの点に重点をおき考察を進めることとする。

(1)各地域の特徵やニーズに応じた道路の管理運用を行

うには，地域性に配慮した指標を取り入れ，地域ご とに目標設定を行い課題に対応していく必要がある。 (2)地域実態を考慮した指標の提案やその評価方法に おいて，実際の道路利用者である地域住民（以下 「利用者」とする）の視点を反映する道路の管理 運用の評価過程を導入するなど，透明性や公正性 を確保し利用者の理解と行政の十分な協働関係を 構成する取り組みを推進していくべきである。

\section{1-3. 既存研究及び研究の目的}

これまでに，道路交通サービスに対する利用者の 意識に着目した研究は数多くみられる2),3),4)。中で も道路の管理運用に対する利用者の視点に着目した ものとして，望月ら ${ }^{5}$ は，幹線道路事業に対する沿 道住民の意識構造を分析し考察を試みており，その 結果，幹線道路事業に対する住民の関心程度や評価，
そして賛否が相互に影響し合っていることを明らか にしている。また，行政対応の評価に対する利用者 の視点を考慮した評価指標に関するものとして，平 石ら ${ }^{6}$ は，事業量の達成指標に加え成果指標を含む 交通施策評価に関わる複数の指標について市民・行 政双方による評価を考察し，指標によって市民と行 政間の評価の差が大きくなるといつた交通政策関連 の指標導入の留意点を明らかにしている。

これらの研究は, 道路交通サービスに対する利用 者のニーズや視点からみた行政対応の重要性を明確 にしているものの，行政対応に対する評価として抽 象的な印象を計測するにとどまっており，利用者は これらの行政対応についてどのような視点で評価し ているのか，あるいはこれらの行政対応は利用者に とってどの程度効果があるのかなど, 行政が把握し きれず対応できていないギャップを充足すべきであ るといった課題を残している。そのため, 行政対応 に対する評価として利用者が評価している視点のよ り詳細な分析や検討が必要となり，道路交通サービ スに対する利用者の視点と行政対応の関係を明らか にし定量的に検討する必要がある。

そこで本研究では，冬期道路交通サービスに対し て利用者が実際にどういった視点から評価を行って いるのかを明らかにし, 冬期道路交通サービスの成 果指標を定めるにあたり，地域実態の反映として利 用者の意識を十分考慮した成果指標の提案までのプ ロセスを明確化する。具体的には，以下の3点を目 的とした。

i ）降積雪に見舞われる農山村地域の冬期道路交通 サービスに対する地域実態を利用者への意識調査 から把握し, 利用者の視点から見た冬期道路交通 サービスの提供における重要項目を確認する。

ii）利用者への意識調査の結果を用いて共分散構造 分析を行い, 降積雪時の道路状況に対する利用者 の意識と行政対応に対する評価間の因果構造を分 析し定量化する。

iii）因果構造分析の結果から，利用者の意識に基づ いた冬期道路交通サービスに関する成果指標の提 案について検討を行い, その提案までの体系的な プロセスを明確化する。 


\section{2. 研究の対象地域}

本研究は, 図-1に示すように, 冬期の降積雪が 特に問題となる農山村部の典型的な例として, 福井 県今立郡（現越前市の一部（旧今立町）と池田町） を対象とした。特にこの地域は周囲が山で囲まれ， 森林面積が約 $90 \%$ を占める山間地域であり, 特別豪 雪地帯, 過疎地域, 特定農山村地域に指定されてい る典型的な降積雪のある農山村地域である。

位置的には, 南東部は大野市及び岐阜県, 北西部 は鯖江市や武生市（現越前市の一部）に接しており, 北陸自動車道の武生 IC や鯖江 IC が近く位置して いる。また，隣接市町を結んでいる国道417号が中 部圈と直接つながるため, 交通量の多いことに加え 将来の道路整備によって交通量の更なる増加が見込 まれている。隣接する都市地域である武生市と鯖江 市への通勤・通学者の割合も各々 $5 \%$ 通学通勤圈の 人口比を超える全人口の約 $12 \%$ と $7 \%$ で農山村と都 市との間に多くの人口流動が見られるなど, 同県内 でも交通の要所として非常に重要な位置にある。

平成 12 年の国勢調査による総人口は 17,666 人であ り，表－ 2 に示すように，人口密度も同県内の都市

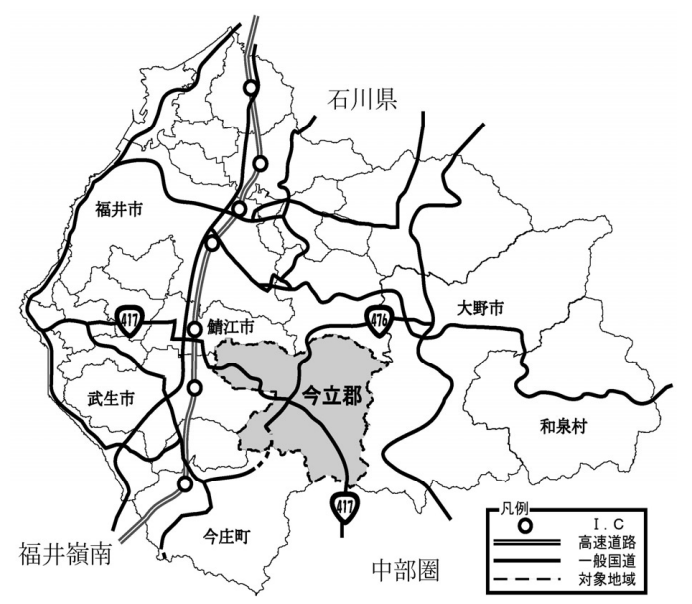

図-1 対象地域と道路網

(2004年 2 月現在)

表 -2 対象地域と近隣地域の現況（2004年 2 月現在）

\begin{tabular}{|c|c|r|r|r|r|}
\hline \multicolumn{2}{|c|}{ 地域 } & $\begin{array}{c}\text { 人口密度 } \\
\text { (人/面積km) }\end{array}$ & $\begin{array}{c}\text { 道路密度 } \\
\text { (延長km/面積 } \\
\left.\mathrm{km}^{2}\right)\end{array}$ & $\begin{array}{c}\text { 宅地面積 } 1 \text { に対 } \\
\text { す農地面積の } \\
\text { 比率 }\end{array}$ & $\begin{array}{c}10 \text { 年平均 } \\
\text { 積雪深 } \mathrm{cm}\end{array}$ \\
\hline $\begin{array}{c}\text { 文象地域 } \\
\text { (農山村部) }\end{array}$ & 今立郡 & 162.7 & 2.2 & 20.9 & 72.7 \\
\hline \hline $\begin{array}{c}\text { 近隣地域 } \\
\text { (都市部) }\end{array}$ & 鯖江市 & 756.8 & 8.1 & 2.5 & 46.8 \\
\cline { 2 - 7 } & 武生市 & 398.2 & 4.4 & 5.0 & 45.4 \\
\hline
\end{tabular}

部と比べ低く, また道路密度も低いことから, 生活 道路が同時に主要幹線道路でもある状況にある。さ らに, 雪の量も多く, 最近 10 年間の平均積雪深は $72.7 \mathrm{~cm}$ であり, 特に多くの雪に見舞われる地域と して安定的かつ安心できる道路交通の確保が極めて 重要である。

\section{3. 冬期道路交通サービスに対する利用者意識}

人は様々な生活環境や価値観を持っており, それ らを考慮し利用者が望む冬期道路交通サービスを提 供することが重要である。そのため, 降積雪時の道 路状況や行政対応の評価に対する利用者意識を十分 把握し，それを踏まえた上で冬期道路交通サービス の提供における優先されるべき項目を検討する必要 がある。そこで本章では, 降積雪時の自動車及び歩 行者の移動, 生活の実態に加え, 行政対応に対する 評価における利用者の意識調査により, 冬期の道路 交通状況に対する利用者の視点と, 冬期道路交通サ一 ビスの提供における重要項目を明らかにする。

\section{3-1. 調査概要}

対象地域を活動の拠点としている15歳以上の方を 対象 ${ }^{(i 2}{ }^{3} に$ 意識調査を行った。調査概要及び質問内 容は表ー 3 に示すとおりである。

\begin{tabular}{ll} 
& 表 -3 調査概要 \\
\hline ·調查時期 & 2004 年 2 月中旬 \\
·対象地域 & 福井県今立郡 \\
·調查対象 & 対象地域を活動拠点とする 15 歳以上の方 \\
·調查方法 & 留置調査法 \\
·配布数 & 210 票 \\
(母集団: $17,666 、$ 精度: 0.07 、信頼度: 0.95 、標本数: 194$)$ \\
·抽出率 & $1.1 \%$ \\
·回収数 & 160 票(回収率: $76.2 \%)$ \\
·有効サンプ数 127 票(有効回収率 $60.5 \%)$ \\
·質問内容 & 問 1. 個人属性 \\
& 問 2. 降積雪時の自動車移動の実態 \\
& 問 3. 降積雪時の歩行者移動の実態 \\
& 問 4. 降積雪時の生活の実態 \\
& 問 5. 降積雪時の行政対応に対する評価 \\
\hline
\end{tabular}

\section{表 -4 回答者の個人属性}

\begin{tabular}{|c|c|c|c|c|c|c|c|c|c|c|}
\hline \multirow{2}{*}{\multicolumn{2}{|c|}{ 性別 }} & \multirow{2}{*}{\multicolumn{2}{|c|}{ 居住地 }} & \multirow{2}{*}{\multicolumn{2}{|c|}{ 活動地域 }} & \multirow{2}{*}{\multicolumn{2}{|c|}{$\begin{array}{c}\text { 年齢 } \\
\text { (実際構成) }\end{array}$}} & \multicolumn{3}{|c|}{ 主な移動手段 } \\
\hline & & & & & & & & & 普段 & 積雪 \\
\hline \multirow[b]{2}{*}{ 男 } & \multirow[b]{2}{*}{64} & 今 & & 主に郡内 & 67 & 15〜29才 & 18(19) & \multirow{2}{*}{$\begin{array}{l}\text { 自 } \\
\text { 動 } \\
\text { 車 }\end{array}$} & \multirow[b]{2}{*}{83} & \multirow[b]{2}{*}{86} \\
\hline & & 立 & 92 & 郡内外 & 13 & $30 〜 49 才$ & $36(27)$ & & & \\
\hline \multirow{2}{*}{\multicolumn{2}{|c|}{ 女 36}} & 地 & \multirow[b]{2}{*}{8} & \multirow[b]{2}{*}{ 主に郡外” } & \multirow[b]{2}{*}{20} & $50 \sim 64$ 才 & $29(24)$ & \multirow{2}{*}{$\begin{array}{l}\text { そ } \\
\text { の } \\
\text { 他 }\end{array}$} & \multirow[b]{2}{*}{17} & \multirow[b]{2}{*}{14} \\
\hline & & $\begin{array}{l}\text { 域 } \\
\text { 外 }\end{array}$ & & & & 65才以上 & $17(30)$ & & & \\
\hline
\end{tabular}


表－4の回答者の個人属性をみると，回答者の 9 割以上が地域内に居住しており，その活動地域にお いても半数以上が地域内であることから，地域住民 の地域内道路に対する十分な利用経験及び知識をも とに回答されたと考えることができる。また，年齢 構成が対象地域の実際の年齢構成に比べて大きく偏つ ていないため, 地域内の全体年齢層が抱えている地 域実態がおよそ反映できた回答であるといえる。そ して主な交通手段をみると, 回答者の約 8 割が自動 車利用者であるものの, 自動車利用者においても歩 行は一般的に生活上の必要不可欠なものであるため, 歩行環境について十分な認識を持つていると考えら れる。よって, 多数を占める自動車利用者と歩行者 の両視点による地域実態を考慮できるように，回収 した160票のうち,「自動車移動の実態」か「歩行者 移動の実態」の片方のみを回答した33票は除き, 表一 3に示したとおりに実際に両方とも回答した127票を 分析に用いることにした注4。

\section{3-2. 調査結果}

福井県の有職者らの議論 ${ }^{\text {注 }}{ }^{5}$ により抽出した質問 項目を表一 $5^{\text {注6) }}$ に示す。なお, 表の中の問 2 から 4 については，「非常に多い」，「やや多い」，問 5 に ついては，「大変良い」，「やや良い」の回答割合を 示す。

まず，移動の実態である「問 2 自動車の移動」で は，「寒さで凍結した道路を通ること」と「雪でデ コボコになつた道路を通ること」，そして「悪い運 転マナ一の車を見かけること」が多いといつた回答 の割合が高い。また「問 3 歩行者の移動」では, 「交通マナーの悪い車を見かけること」,「消融雪装 置の散水が歩行の妨げになること」と感じている割 合が高い。このことから，降積雪や凍結による路面 状態の悪化などによる走行の不便さを改善すること が重要項目であることと，交通マナーの悪化や道路 の消融雪装置による歩行環境の悪化を改善すること が重要視されていることがわかる。

次に，「問4生活の実態」からは，降積雪によって 業務や通院または買い物などの生活の移動をあきら めることが多いといつた回答の割合は全体的に少な
表－5 各質問項目に対する回答割合

(\%)

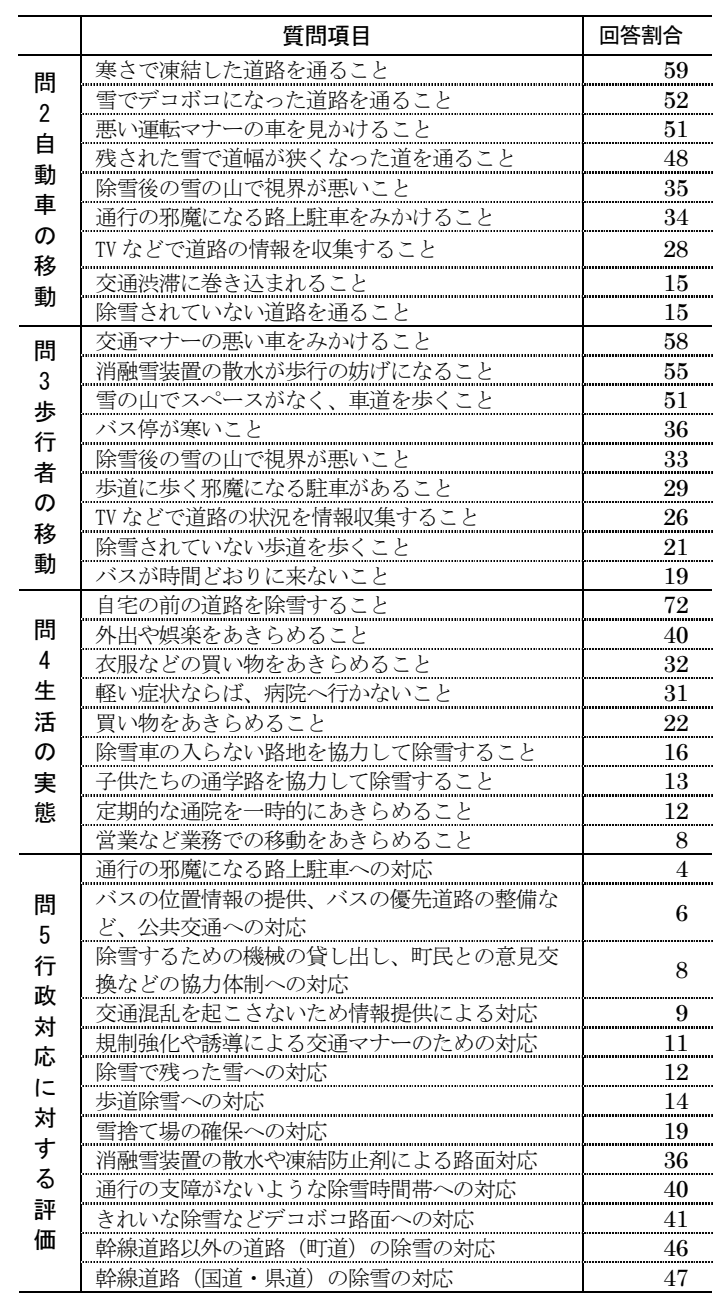

※Kruska1-wa11is $の$ 順位和検定 1\%有意

いが，「自宅の前の道路を除雪すること」が多いと いった回答の割合は非常に高い。ここでは，自宅の 前を除雪することが重要視され, 降積雪時の住民生 活空間の確保のためにも道路などの公共空間の除雪 に対する道路交通サービスの提供が重要視されてい ることがわかる。

一方，「問 5 行政対応に対する評価」では，道路 交通サービスを行っている殆どの行政対応に対して 満足の意見が非常に少ない。これは, 実際に行って いる行政対応に対して利用者が多くの不満を持ち, この地域での道路交通サービスのレベルは低いと判 断していると考えられる。よって, 行政は現在行つ ている冬期道路交通サービスに対する利用者の意識 
についてより的確な把握を行い, 利用者が実際に望 んでいるサービスを提供することが重要である。

以上のことから, 降積雪時の道路状況や行政対応 に対する利用者の意識が明らかになり，これにより 利用者の視点から見た冬期道路交通サービスの提供 における重要項目を確認することができた。このこ とを踏まえ, 冬期の道路状況に対する利用者の視点 に基づいた道路の管理運用を行うことが重要である ことと, サービスの提供における優先されるべき項 目が示唆された。

\section{4. 因果構造モデル}

3-2において利用者が望む冬期道路交通サービス の重要項目を明らかにした。しかし, 項目各々の重 要性は示しているものの総合的な視点からみた道路 交通サービスの向上のためには，それの相互の関連 性を見極めた上でより効果的な改善視点の抽出が不 可欠となる。したがって, 本章では, 共分散構造分 析を適用し, 道路の利用者が, どのような視点から 行政側が提供している道路交通サービスの評価を行つ ているのかを探ることにより, 降積雪時の「自動車
の移動」及び「歩行者の移動」そして「生活の実態」 と,「行政対応に対する評価」間の因果構造を明ら かにする。

\section{4-1. 共分散構造分析}

共分散構造分析とは, 意識調査によって得られた データ（観測変数）と，その背後にあると考えられ る直接計測できない構成概念 (潜在変数) 間の因果 関係を明らかにするものである。分析者は様々な仮 説のもとに自由にモデルを構築することができ，そ の仮説の有意性を検証する場合に有効な分析手法で ある。

$$
\begin{aligned}
& \eta=\mathrm{B} \eta+\Gamma \xi+\zeta \\
& \chi=\mathrm{K} \eta+\mathrm{A} \xi+e
\end{aligned}
$$

$$
\begin{array}{cll}
\text { ただし }, & : & \text { 内生潜在変数ベクトル } \\
\xi & : & \text { 外生潜在変数ベクトル } \\
\chi & : & \text { 観測変数ベクトル } \\
\zeta, e & : & \text { 誤差項ベクトル } \\
\mathrm{B}, \Gamma, \mathrm{K}, \mathrm{A} & : & \text { パラメータ行列 }
\end{array}
$$

\begin{tabular}{|c|c|c|c|c|c|c|}
\hline 変数名 & 第 1 因子 & 第 2 因子 & 第 3 因子 & 第 4 因子 & 第 5 因子 & 第 6 因子 \\
\hline きれいな除雪などデコボコ路面への対応 & 0.83 & 0.14 & -0.02 & 0.16 & 0.16 & 0.17 \\
\hline 幹線道路以外の道路 (町道) の除雪対応 & 0.83 & 0.14 & 0.05 & 0.23 & 0.08 & 0.05 \\
\hline 通行の支障がないような除雪時間帯への対応 & 0.77 & -0.02 & 0.20 & -0.03 & 0.07 & 0.13 \\
\hline 除雪で残つた雪への対応 & 0.72 & 0.22 & -0.03 & 0.07 & 0.11 & 0.13 \\
\hline 歩道除雪への対応 & 0.70 & 0.21 & 0.00 & 0.06 & 0.13 & 0.33 \\
\hline 幹線道路（国道・県道）の除雪対応 & 0.67 & 0.02 & 0.24 & 0.19 & 0.03 & 0.18 \\
\hline 雪の山でスペースがなく、車道を歩くこと & 0.18 & 0.77 & 0.09 & -0.04 & 0.30 & 0.08 \\
\hline 除雪されていない歩道を歩くこと & 0.17 & 0.67 & 0.08 & 0.07 & 0.27 & 0.08 \\
\hline 消融雪装置の散水が歩行の妨げになること & 0.06 & 0.67 & 0.15 & " & 0.00 & 0.09 \\
\hline 歩道に歩く邪魔になる駐車があること & 0.20 & 0.50 & -0.05 & 0.24 & 0.47 & 0.19 \\
\hline 食料品などの買い物をあきらめること & 0.09 & 0.04 & 0.89 & 0.03 & 0.08 & 0.02 \\
\hline 外出や娛楽をあきらめること & -0.01 & 0.32 & 0.79 & 0.02 & 0.16 & 0.01 \\
\hline 軽い症状ならば、病院へ行かないこと & 0.17 & 0.04 & 0.75 & 0.05 & 0.05 & 0.13 \\
\hline 交通マナーの悪い車をみかけること & 0.23 & 0.12 & 0.14 & 0.72 & 0.13 & 0.08 \\
\hline 通行の邪魔になる路上駐車をみかけること & 0.18 & -0.06 & -0.07 & 0.63 & 0.23 & 0.32 \\
\hline 交通踮滞に巻き込まれること & 0.20 & 0.01 & -0.13 & 0.61 & 0.34 & 0.14 \\
\hline TVなどで道路の情報を収集するこど & -0.15 & 0.28 & 0.13 & " 0.48 & 0.20 & -0.11 \\
\hline 悪い運転マナーの車を見かけること & 0.25 & 0.44 & 0.12 & 0.47 & -0.14 & 0.13 \\
\hline 寒さで涷結した道路を通ること & -0.02 & 0.12 & 0.12 & 0.13 & 0.65 & -0.04 \\
\hline 雪でデコボコになつた道路を通ること & 0.24 & 0.12 & 0.10 & 0.24 & 0.60 & 0.21 \\
\hline 除雪されていない道路を通ること & 0.25 & 0.34 & 0.22 & 0.23 & 0.52 & 0.22 \\
\hline 除雪された雪で非常に狭くなった道を通ること & 0.40 & 0.34 & 0.06 & 0.17 & 0.51 & 0.13 \\
\hline 交通混乱を起こさないための情報提供による対応 & 0.18 & 0.14 & 0.11 & 0.10 & -0.06 & 0.69 \\
\hline 規制強化や誘導による交通マナーのための対応 & 0.20 & 0.01 & 0.05 & 0.06 & 0.10 & 0.74 \\
\hline 通行の邪魔になる路上駐車への対応 & 0.18 & 0.16 & 0.02 & 0.12 & 0.21 & 0.55 \\
\hline 第 6 因子の固有値 & 4.16 & 2.58 & 2.27 & 2.12 & 2.12 & 1.88 \\
\hline 第 6 因子の寄与率 (\%) & 16.66 & 10.32 & 9.06 & 8.49 & 8.47 & 7.51 \\
\hline 第 6 因子までの累積寄与率（\%） & 16.66 & 26.98 & 36.05 & 44.54 & 53.01 & 60.52 \\
\hline
\end{tabular}

(1)は潜在変数間の因果構造を表す構造方程式で

\section{表－6 因子分析の結果（バリマックス法）}


あり, (2)は観測変数と潜在変数との間の因果構造 を表す観測方程式である。

本研究では, 因子分析から得られる因子を構成概 念（潜在変数）としてモデルを構築し, 観測変数の 共分散構造行列をこれらの方程式モデルのパラメー 夕によって構造化した後, パラメー夕を推定する。 これにより, 利用者と行政間の把握できない各変数 間の相関関係や因果関係の強弱が説明でき，その関 係性を数值化し定量化することにより利用者の視点 やニーズに対応した道路交通サービスにおける各項 目の重要度を明確にすることができる。

\section{4-2. 潜在変数の設定}

因果構造モデルにおける観測変数には, 表一5で 示したデー夕を用いる。分析には, 順序尺度のみを 使用するため, 無回答が多い質問項目の一部を削除 した。次に, 多重共線性を考慮し, 質問項目間の相 関分析を行い，相関が非常に高い（相関係数 0.8 以 上）質問項目を削除した。さらに, より明確な結果 を得るため, シグマ值法注7により簡便な 5 段階の 順序尺度を間隔尺度に変換した。

以上のクリーニングを行つたデータを用い, 因子 分析を行うことにより, 観測変数がどのような構成 概念（潜在変数）によって分類されるのかを明らか にする。共通性の推定は, 相関行列の絶対值を最大 值とし, 因子負荷量の算定には, 主因子法を用い直 交回転（バリマックス回転）を行った。その結果， 因子解釈のしゃすさ, 固有值の大きさを考慮して固 有值が 1.0 以上である 6 つの因子を構成概念（潜在 変数）として利用する。なお，6つの因子に対する 各変数を, 因子負荷量順に並び替え表一 6 に示す。

ここで, これらの 6 因子について, 因子負荷量に 基づき, 観測変数との関係からその意味を考察する。 第 1 因子は,「行政対応に対する評価」の項目のう ち, 幹線道路やその以外の道路, そして路面除雪に よる対応との関連が強いことから,「行政のハード 的整備に対する評価」と解釈する。以下同様に，第 2 因子は, 歩行時の危険性と関連が強いことから, 「歩行者移動の安全性」と解釈する。第 3 因子は, 降積雪による住民生活のマイナス影響と関連が強い
ことから，「生活における移動の制約」と解釈する。 第 4 因子は, 移動の不快感と関連が強いことから 「移動の快適性と円滑性」と解釈する。第 5 因子は, 自動車移動の危険性と関連が強いことから「自動車 移動の安全性」と解釈する。最後に, 第 6 因子は, 間接的な道路整備と関連が強いことから「行政のソ フト的整備による対応」と解釈する。

\section{4-3. 因果構造モデルの解釈}

モデルの推定にはパッケージソフト AMOS 5.0を 用いた。このモデルは, 因子分析の結果からの $6 \supset$ の因子を構成概念 (潜在変数) とし, 各種の冬期道 路交通環境が利用者の意識に結びつき，さらにそれ らは行政対応に影響するという仮説を立て, この仮 説をもとにパスの引き方を検討した結果, 最も適合 度が高かったモデルである。構築した仮説モデルを 図ー 2 に示し, 表一 6 の各質問項目を簡潔にまとめ, 採用したパス図とパラメータの推定結果を図ー 3 に 示す。モデルの適合度注8) は GFI $=0.741, \mathrm{CFI}=0.878$, RMSEA=0.075であり， GFI と CFI とも 1.0 に近く RMSEA が0.10以下であるため以下に考察を行う。 ここで，回答者の性別及び年齢を観測変数とする, 個人属性といつた潜在変数の影響は殆ど見られず, モデルの適合度 $(\mathrm{GFI}=0.728, \mathrm{CFI}=0.855$, RMSEA $=0.077)$ も低下するため対象外とした。なお, 観測 方程式における潜在変数から観測変数へのパラメー 夕は, すべてが統計的に $1 \%$ 水準で有意な結果が得 られた。

分析の結果から全体的にみると,「自動車移動の

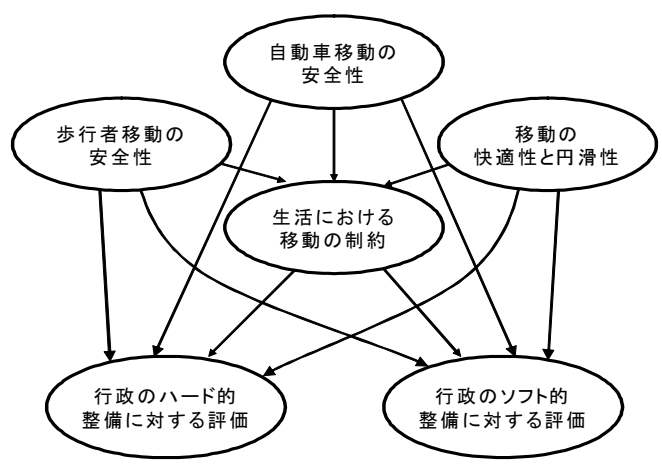

図ー 2 モデルの仮説 
安全性」が「生活における移動の制約」、「行政のソ フト的整備に対する評価」そして「行政のハード的 整備に対する評価」へそれぞれ強い影響を与えてい る（相関関係：0.40，0.39，0.43）。これは, 降積雪 時には, 徒歩より自動車が主な移動手段であること を表しており,「自動車移動の安全性」を確保する ことが「生活における移動の制約」を緩和させるだ けでなく,「行政のハード的整備に対する評価」及 び「行政のソフト的整備に対する評価」を高めると 考えられる。

また, 「移動の快適性と円滑性」及び「歩行者移 動の安全性」は,「生活における移動の制約」や 「行政の整備に対する評価」へ与えている影響は殆 どみられず,「自動車移動の安全性」との相関関係 の夕が高い值を示している（相関係数：0.64，0.72）。 特に, 「歩行者移動の安全性」と「移動の快適性と 円滑性」を構成している観測変数の中で,「除雪後 の車道を歩くこと」と「悪い運転マナー」が高い值 (因果係数：0.88，0.78）を示していることから, 降積雪時には, 歩行者が自動車と混じり合いながら 同じ車道を利用することが地域住民にとつて重要な 問題として認識されていることを示唆する。すなわ ち, 運転者の安全なドライブや自動車の安全な移動 が歩行者移動の安全と直結していることとなり,

「自動車移動の安全性」の確保が「移動の快適性と円
滑性」及び「歩行者移動の安全性」を向上させると いえる。

しかし「生活における移動の制約」が「行政のハー ド・ソフト的整備に対する評価」へ影響を与えると 仮定したが，その影響はほとんどみられなかった (相関係数: $0.00,0.02$ )。このことから, 行政対応 に対する評価には「生活における移動の制約」に関 連せず，移動を取り巻く環境として自動車移動の安 全性が直接的に影響を与えることが読み取れる。

以上のことを踏まえ, 移動の実態と行政の整備に 対する評価の因果関係をみると, 移動の実態として 「自動車移動の安全性」が「行政のハード的整備に 対する評価」及び「行政のソフト的整備に対する評 価」に影響を与えている（相関関係：0.39，0.43）。 また, この「自動車移動の安全性」を構成している 観測変数をみると, 「非除雪道路を通る」と「狭く なった道路を通る」, そして「デコボコ道路を通る」 といつた観測変数と因果関係が高いことを示してい る (因果係数: $0.80,0.77,0.70)$ 。このことから, 道 路の除雪を行うことや除雪時の堆雪によって道路が 狭くなるのを防ぐこと, そして適時の除雪によるデ コボコのない綺麗な路面を維持することが「自動車 移動の安全性」のための提供されるべき道路交通サー ビスとしてより重要視されていると考えられ，この ような道路環境を整備することが「行政のハード的

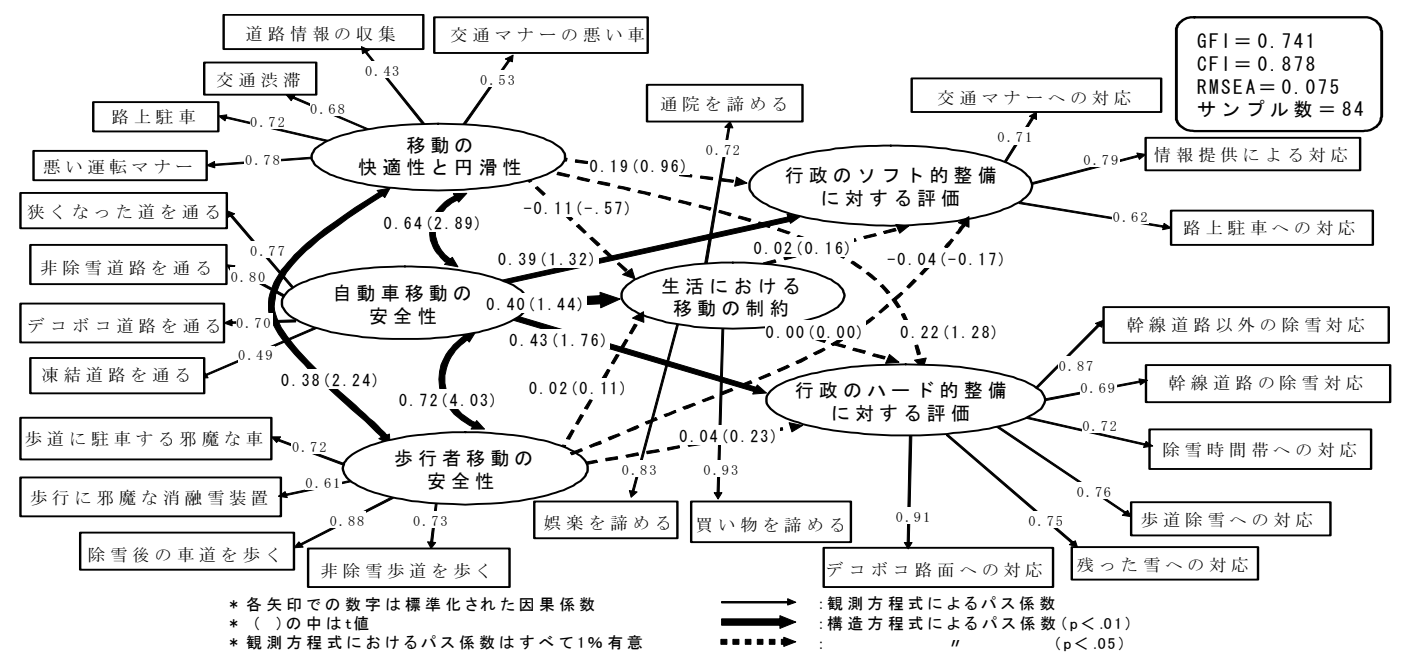

図一３因果構造モデル 
整備に対する評価」及び「行政のソフト的整備に対 する評価」に高い効果を持っていると考えられる。

\section{5. 因果構造による成果指標の検討}

4-3で明らかになった因果構造より, 冬期道路交 通サービスに対する評価を高めるためには，主に 「自動車移動の安全性」に重点を置いた冬期道路交 通サービスを提供することが重要であることがわかつ た。

ここで,「自動車移動の安全性」を構成している 観測変数の中で, 因果関係の強い 3 つの観測変数を 絞り込み，それぞれの対応として適合する成果指標 の例を取り上げる。なお，この「自動車移動の安全 性」から強い影響を受けている2つの潜在変数と, 取り上げた成果指標をあわせて整理し図ー 4 に示す。 また, この「自動車移動の安全性」と強い相関関係 を持つ 2 つの潜在変数と, 図ー 4 で提案を試みた成 果指標との関係を図ー 5 に示す。

\section{5-1. 利用者と行政対応間の因果構造による成果指標}

図ー4 をみると, まず,「除雪されていない道路 を通ること」（因果係数：0.80）の観測変数から， 冬期には運転しにくい路面状況が発生しやすく, 走 行環境を著しく低下させる状況であることが考えら れるため, 町内道路などの除雪による安定した生活
道路の確保が必要であると示唆される。そのため, 成果指標として「除雪された生活道路の確保」を取 り上げ, 住民生活と直結している町内道路（生活道 路）の除雪された道路延長の割合を算定して示す。

次に「残雪で狭くなった道路を通ること」（因果 係数：0.77）からは, 除雪後の堆雪による車道及び 歩道の幅員減少が円滑な通行機能を妨げると考えら れるため, 堆雪場の確保などによる道路幅員の確保 が必要であると示唆される。よって, 成果指標とし て「堆雪後の道路幅員の増加」をあげ, 堆雪場確保 や迷惑駐車抑制による道路幅員の確保率を算定して 示す。

最後に,「雪でデコボコになつた道路を通ること」 （因果係数：0.70）があげられ，主に朝ピーク時の 除雪後の降雪により, 自動車交通量の多い場所にデ コボコが発生すると考えられる。そのため, データ 収集などからデコボコの頻出地点を抽出し, 消融雪 装置の設置などを通じた路面の改善が必要であると 示唆される。よって, 成果指標として「危険な路面 状態の改善」があげられ, デコボコ頻出地点の延長 のうち対策が行われた延長の割合を算定して示す。

また, 図一 5 に示すように, これらの成果指標は, 道路利用者の視点として「自動車移動の安全性」だ けでなく, 地域実態として住民意識が抱えている 「歩行者移動の安全性」と「移動の快適性・円滑性」

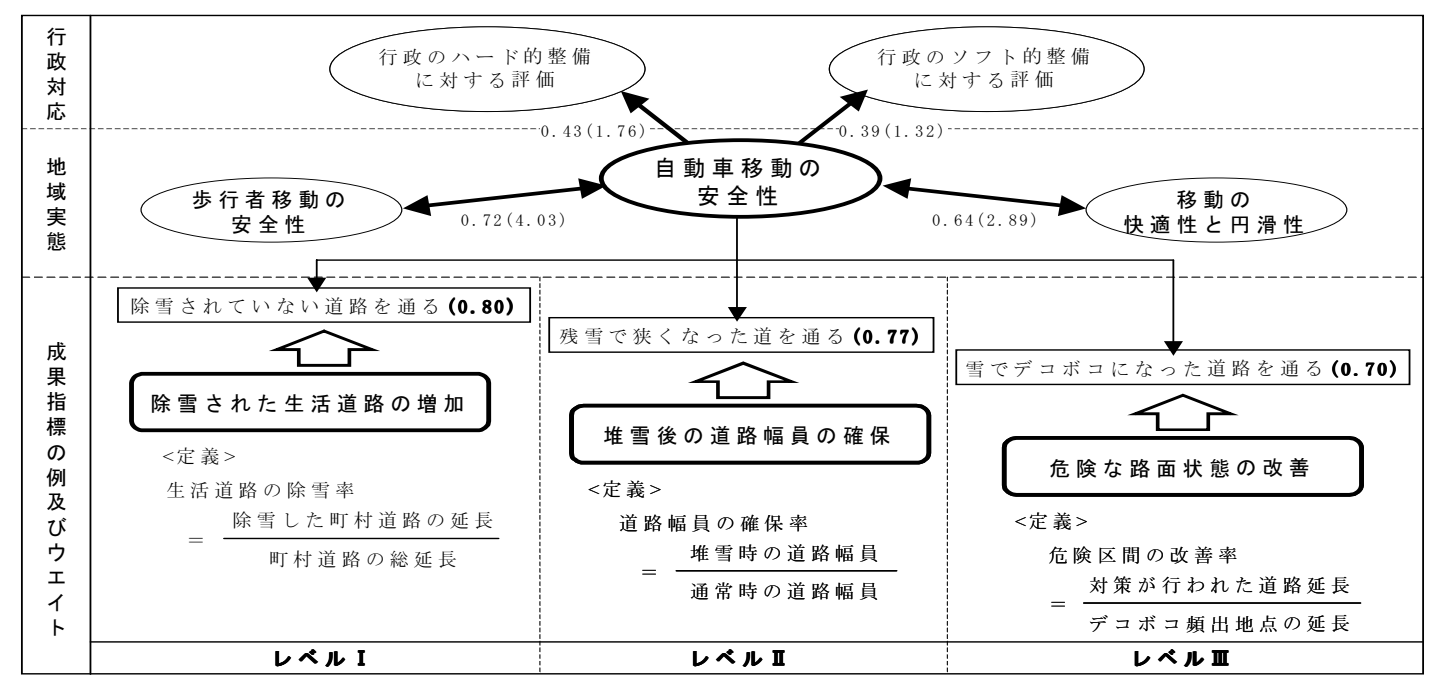

図－4 因果構造による成果指標の検討 


\begin{tabular}{|c|c|c|c|c|}
\hline \multirow{2}{*}{$\begin{array}{l}\text { 地域 } \\
\text { 実態 }\end{array}$} & \multirow[b]{2}{*}{ 道路交通サービスに対する住民意識 } & \multicolumn{3}{|c|}{ 成果指標の例 } \\
\hline & & 除雪された生活道路の増加 & 堆雪後の道路幅員の確保 & 危険な路面状態の改善 \\
\hline \multirow{3}{*}{$\begin{array}{l}\text { 自動車 } \\
\text { 移動の } \\
\text { 安全性 }\end{array}$} & 除雪されていない道路を通ること $(0.80)$ & $\boldsymbol{0}$ & 0 & 0 \\
\hline & 残雪で道幅が狭くなった道を通ること $(0.77)$ & $\mathbf{O}$ & 0 & $\Delta$ \\
\hline & 雪でデコボコになった道路を通ること $(0.70)$ & $\Delta$ & 0 & $\bullet$ \\
\hline \multirow{3}{*}{$\begin{array}{l}\text { 歩行者 } \\
\text { 移動の } \\
\text { 宔性 }\end{array}$} & 除雪後に車道を歩くこと $(0.88)$ & (0) & $\bigcirc$ & $\bigcirc$ \\
\hline & 除雪されていない歩道をあるくこと $(0.73)$ & $\bigcirc$ & $\bigcirc$ & $\triangle$ \\
\hline & 歩行に邪魔になる歩道駐車をみかける $(0.72)$ & $\bigcirc$ & $\bigcirc$ & $\triangle$ \\
\hline \multirow{3}{*}{$\begin{array}{l}\text { 移動の } \\
\text { 快適性 } \\
\text { 円滑性 }\end{array}$} & 運転マナ一の悪い車をみかけること $(0.78)$ & $\triangle$ & $\triangle$ & $\bigcirc$ \\
\hline & 通行に邪魔になる路上駐車をみかける $(0.72)$ & $\bigcirc$ & (a) & $\triangle$ \\
\hline & 交通踏滞に巻き込まれること $(0.68)$ & $\bigcirc$ & 0 & 0 \\
\hline
\end{tabular}

(@：直接的関連がある、○：間接的関連がある、 $\triangle$ : 関連が少ない)

図ー 5 地域実態として住民意識を考慮した成果指標の検討

に対する問題点とも直接的・間接的に関連している。 そのため,「歩行者移動の安全性」と「移動の快適 性・円滑性」に対する行政の対応としても更なる成 果を得ることができる。

\section{5-2. 因果係数のウエイトによる成果指標}

5-1で取り上げた成果指標では，3-3で明らかにし た降積雪時の道路状況や行政対応に対する利用者の 意識に加え, 利用者の意識と行政対応間の因果関係 の定量化と, 行政の対応に対する評価として利用者 の視点のより詳細な検証, そして利用者のニーズや 要望を満たすことができるより効果的な冬期道路交 通サービスの提供における改善視点が検証できた。

ここで, 図ー 4 に示したとおりに, 潜在変数を構 成している各々の観測変数との因果関係に基づくそ れぞれの因果係数を, 行政の道路交通サービスに対 する利用者意識が持つウエイトとして捉えることで, 各ウエイトによる冬期道路交通サービスのレベルを 設定することが可能となる。たとえば，サービスレ ベル I として, この地域は幹線道路の除雪のみでは 高い評価を得ることが期待できない地域特徵を持つ ため, 幹線道路より生活中心に利用されている道路 の除雪が最も優先されるべき項目であると考えられ, 冬期道路交通サービスに関する行政対応の中でも生 活道路の除雪といつた行政対応が改善される重要項
目であることを示唆することが可能となる。同様に サービスレベル II とIII として，デコボコ路面への対 応のための危険な路面状態の改善よりは, レベルの 高い道路の狭小化への対応のための道路幅員の確保 が優先されるべき項目であるなど, 利用者の視点に より道路交通サービスのレベルを順序づけることに よって, 各レベルの優先順位に基づく冬期道路交通 サービスの提供を実現することが可能となる。

さらに, 各地域の特徵や実態による地域差などを 勘案すると, 各観測変数のウエイトや必要とするサー ビスのレベルが少しずつ違つてくることが想定され るため, 利用者意識に基づいた各観測変数間の組み 合わせにより, 地域実態に合わせた固有の合成指標 の検討が可能となり, 地域実態に適合した新たな指 標を提案することが可能となる。

\section{6.おわりに}

本研究では, 利用者意識に基づいた冬期道路交通 サービスの評価についての検討を行い, 以下のよう な結果を得た。

(1)冬期道路交通サービスに対する利用者意識

農山村地域における降積雪時の道路状況に対する 地域実態として自動車及び歩行者の移動, 生活の実 態に加え, 行政対応に対する評価における利用者の 意識調查を行い, 利用者の視点から見た冬期道路交 
通サービスにおける重要項目を明らかにした。

(2)利用者意識と行政対応の因果関係

利用者意識調査の結果を用いて共分散構造分析を 行い, 利用者意識と行政対応間の因果構造を分析し た結果，行政対応に対する評価を高めるより効果的 な行政対応のためには, 自動車移動の安全性に関連 した冬期道路交通サービスの提供や改善が重要であ ることを明らかにした。

(3)因果構造による成果指標の検討

共分散構造分析による因果構造分析の結果から, 利用者の意識に基づいた冬期道路交通サービスに対 する成果指標の提案について検討を行つた。その結 果, 地域実態に基づいた利用者意識を体系的に分析 しその結果を反映した成果指標の提案が可能になつ た。

以上により, 現在行われている様々な道路交通サー ビスの中でも利用者が実際に求めている行政対応の 重要度や優先すべき項目が明示的に示されることと なり，利用者のニーズをより満たすことができる成 果指標の提案における体系的なプロセスが明確化さ れた。

しかし, 現在の各市町村が有している道路関連や 除雪関連に関するデータでは, これらの成果指標を 算出することが困難である。したがって, 今後は, これらの指標を算出するための簡便でかつ定期的, 継続的なデー夕の収集が必要である。また, これら の指標が他の農山村地域の道路でも適用可能かを検 討するため, 成果指標の適用事例を増やし, 冬期道 路交通サービスの価值基準に関するデータを蓄積し ていく必要がある。

最後に, 行政政策といつた観点からは, 全ての利 用者を考慮したサービスの提供が最も望ましい考え 方であり，それによって高い評価を得ることができ る。そのため, 今後視点を絞込み, 高齢者や子供な どのいわゆる交通弱者までを対象としたより詳細な 研究を行う必要がある。また, 本研究は, 限定され た地域の調査結果であり, この結果を直ちに一般化 することは難しい。よって, 今後このような利用者 の意識が考慮できるプロセスの理論的枠組みを用い た調査研究を行い, 地域的特徵や利用者の意識が反
映された成果指標の提案の一般化や妥当性について さらに検討する必要がある。

\section{補注}

1) 指標には, インプット指標, アウトプット指標, アウトカム指標という三つの種類がある。これは, 「実施」段階において予算や人員などの資源を示 す「インプット (投入)」, 提供するサービスを示 す「アウトプット (算出)」, アウトプットを利用 者側の便益や満足度で捉えた「アウトカム（成果）」 という「流れ」がある。

2 ）成果指標（アウトカム指標）とは, 「ある政策 によりサービス（ある施策の対象者に直接提供さ れた金銭，モノ，またはサービス等）を提供した 結果として国民にもたらす成果を指標としたもの」 と定義されている。すなわち, 誰もが簡単に理解 でき, 客観的「効果」を推測しうる指標である。 ここで,「効果」とは「政策に基づき実施し, 又 は実施しょうとしている行政上の一連の行為が国 民生活及び社会経済に及ぼす又は及ぼすことが見 込まれる影響」と定義される。この「影響」が成 果に当たる。

3 ）意識調査の内容が個人の性向よりは地域の全般 的な実態の把握を目的としているため, 交通行為 における子供の安全を守ることは壮年層にとって は一般的な社会動向として捉えられ, 社会的な判 断能力が未成熟と考えられる15歳以下の方の意見 については直接的には調査を行っていない。

4 ) 本研究は, 自動車利用者と歩行者の両方の視点 からの均衡のある評価を行うスタンスを取ってい るため, 自動車および歩行者片方のみの回答は除 外することとした。「自動車移動の実態」のみを 回答したサンプル数は約 $17 \%$ （28/160票）であ り, 特に,「歩行者移動の実態」のみを回答した サンプル数は, 地域全体の意見であるとは考え難 い程度の約 $3 \%$ （5/160票）に過ぎなかった。

5 ) 既存関連研究などを参考に, 福井県在住の冬期 道路管理に専門知識を持つ有職者 9 名（うち学職 経験者 1 名, 県道路管理運用担当者 5 名, 今立郡 道路管理担当 2 名, その他民間事業所技術者 1 名) 
による福井県の「雪に強い道づくりのためのビジョ ンの策定」 ${ }^{\top} の$ 基礎資料作成を目的とした議論か ら, 降積雪時の道路状況と考えられる地域実態を 絞り込んで抽出した。

6 ）各質問項目の問 2 から問 4 については,「非常 に多い」「やや多い」「やや少ない」「非常に少な い」「一度もない」, 問 5 については「大変良い」 「やや良い」「ふつう」「やや悪い」「大変悪い」の それぞれ 5 段階で回答を得ている。

7 ）ある個人のある特定の意見に対する態度は, 一 つの態度尺度上で基準正規分布をする確率変数で あると仮定する。この態度尺度上には a,b,c,d と いう 4 個の区分点があり（ 5 段階評価の場合）態 度を表す確率変数 $\mathrm{x}$ が $\mathrm{a}$ 以下の值をとつたとき は「重要でない」という反応が生じ， $\mathrm{a}$ と b の間 の值をとつたときは「あまり重要でない」という 反応が生じ，…… d 以上の值をとつたときは 「極めて重要である」という反応が生じると仮定 する。このとき，それぞれの区間（a～d ）にお ける平均值を, 各段階の反応に対応する尺度值 （反応の得点）として定める。このように算出さ れた尺度值を本調查では使用している ${ }^{8)}$ 。

8 ）適合度指標には, 一般的に GFI, CFI, RMSEA があり，モデルの適合度はこの 4 つをおさえてお けば受容して良いと判断する。GFI と CFI とも に0.000〜1.000であり, その值が1.000に近いほど 当てはまりが良いと判断する。 RMSEA は, 0.10 以上は悪い当てはまりであると判断する。

\section{参考文献}

1 ）成果主義の道路行政マネジメントへの転換, 国 土交通省道路行政マネジメント研究会, 2003.

2 ) 山岡俊一, 坂本淳, 利用者の意識と行為に基づ く交差点の評価に関する基礎的研究, 交通工学 pp.77-87, Vol.39, No.2, 2004.

3 ) 栗原真行, 松井健一, 藤本聡, 国土交通政策の 実績評価指標の充実のための検討, 土木計画学 研究・講演集, Vol.24-1, 2001.

4 ) 近藤光男, 廣瀬義伸, 加藤均, 岸本紘典, 都市 の特徵を生かした交通政策の提案と効果分析, 第34回日本都市計画学会学術研究論文集, pp. 913-918, 1999.

5 ) 望月拓郎, 寺部慎太郎, 幹線道路事業における 周辺住民の行政対応に対する評価と事業への関 心程度に関する研究, 第34回日本都市計画学会 学術研究論文集, pp.925-930, 1999.

6 ) 平石造之, 酒井博之, 原田昇, 市民・行政双方 からみた交通施策関連指標についての考察, 55 回土木学会第年次学術講演会, No. IV - 405, 2000.

7 ) (財)地域環境研究所, 雪寒対策調査委託成果報 告書, 2003.

8 ) 大山正, 心理測定 - 統計法, 有斐閣, 1971.

9 ）この 1 年の動き, 神奈川県図書館協会, 協会報, No.207, 2004.

10）Keywords 039アウトカム指標（その 2 ), キー ワード解説, 三菱総合研究所社会システム研究 本部, 2003. 